University of California, Hastings College of the Law UC Hastings Scholarship Repository

Faculty Scholarship

2007

\title{
Genes and Spleens: Property, Contract, or Privacy Rights in the Human Body?
}

Radhika Rao

UC Hastings College of the Law, raor@uchastings.edu

Follow this and additional works at: http://repository.uchastings.edu/faculty_scholarship

Part of the Medical Jurisprudence Commons

\section{Recommended Citation}

Radhika Rao, Genes and Spleens: Property, Contract, or Privacy Rights in the Human Body?, 35 Journal of Law 371 (2007). Available at: http://repository.uchastings.edu/faculty_scholarship/654

This Article is brought to you for free and open access by UC Hastings Scholarship Repository. It has been accepted for inclusion in Faculty Scholarship by an authorized administrator of UC Hastings Scholarship Repository. For more information, please contact marcusc@uchastings.edu. 


\title{
UNIVERSITY of CALIFORNIA HASTINGS COLLEGE OF THE LAW
}

\section{Faculty Publications}

UC Hastings College of the Law Library

\author{
Author: Radhika Rao \\ Source: $\quad$ Journal of Law, Medicine \& Ethics \\ Citation: $\quad 35$ J.L. Med. \& Ethics 371 (2007). \\ Title: $\quad$ Genes and Spleens: Property, Contract, or Privacy Rights in the Human Body?
}

Originally published in JOURNAL OF LAW, MEDICINE \& ETHICS. This article is reprinted with permission from Journal of LAW, Medicine \& ETHICS and American Society of LaW, Medicine \& Ethics. 
Genes and

Spleens: Property,

Contract, or

\section{Privacy Rights in the Human Body?}

Radhika Rao

\section{Introduction}

The legal status of the human body is hotly contested, yet the law of the body remains in a state of confusion and chaos. Sometimes the body is treated as an object of property, sometimes it is dealt with under the rubric of contract, and sometimes it is not conceived as property at all, but rather as the subject of privacy rights. ${ }^{1}$ Which body of law should become the law of the body? This question is even more pressing in the context of current biomedical research, which permits commodification and commercialization of the body by everyone except the person who provides the "raw materials."2 The lack of property protection for tangible parts of the human body is in stark contrast to the extensive protection granted to intellectual property in the body in the form of patents upon human genes and cell lines. Moreover, even courts that reject ownership claims on the part of those who supply body parts appear willing to grant property rights to scientists, universities, and others who use those body parts to conduct research and create products.

Why is the law willing to confer property rights upon some while denying the same rights to others? At first glance, the lopsided treatment of the human body seems to stem from the distinction between physical body parts and intellectual property in the body. Specifically, body parts are seen as a form of raw material to be harvested, whereas human genes and cell lines are conceptualized as a kind of man-made technology. Hence the "inventor" or "discoverer" of intellectual property in the body is granted broad protection that extends across space and time, whereas bodily property is conceived as a tangible thing that is protected only insofar as it remains in the possession of its "owner," or that may be deemed un-ownable and thus not protected at all. But even physical body parts may receive property protection when they are in the possession of a scientist rather than an ordinary person, which suggests that the divergence lies deeper than a distinction between tangible body parts and intellectual property in the body.

I believe that these contradictions in the legal treatment of the human body flow from several important but unstated assumptions about the concept of property itself. First, property implicitly privileges some notions of value over others. Utilitarian and commercial values appear to predominate over other values, which are often ignored or not capable of being fully articulated in the language of property law. Second, property law appears to be weighted in favor of some kinds of regimes over others: private property appears

Radhika Rao, J.D., is a Professor of Law at the University of California, Hastings School of Laze. 
to hold sway over communal property and the public domain. Finally, a fundamental disagreement exists over the ultimate goal of property - whether it is control over the property or the right to receive compensation. Ironically, this may force individuals who resist commodification and commercialization of their bodies to adopt a legal framework that appears at odds with their own arguments in order to articulate their injury and render it legally cognizable. Of course, none of these assumptions necessarily follows from the right to property. To the contrary, all of them manifest a clash between dramatically different understandings of the concept of property.

When those who supply body parts for medical research fail to receive shelter under the law of property, they often attempt to obtain ownership over their own bodies by means of contract or invoke the elusive right to privacy. But neither contract nor privacy is an adequate substitute for the bundle of rights bestowed by property. Unlike property, contract law binds only those who are parties to the agreement, not the whole world. Furthermore, contracts cannot protect those who lack the knowledge or power to negotiate effectively. And unlike property, privacy provides only the right to consent or refuse to permit use of one's body parts for research, not the right to control the course of the research or share in the profits. In addition, privacy implicitly calls for situations of intimacy and relationships that may not exist between researchers and those who participate in medical research.

\section{Three Paradigms for Legal Regulation of the Human Body}

A. The Body as Property

There are three important cases in which individuals have claimed ownership of their own bodies in the context of biomedical research. In all three cases, the courts refused to accord property rights to those who supply body parts for medical research, although the same courts were willing to recognize the property rights of other persons in the body parts themselves and in the resulting products. Almost every student of property law is familiar with the first case, Moore $v$. Regents of the University of California, ${ }^{3}$ in which the California Supreme Court ruled that Moore's spleen was not his property. At the same time, the court found that the Mo cell line - which had been created from Moore's spleen cells and, ironically, named after him - was the property of the researchers who had been granted a patent upon it. Although the court permitted Moore's claims for breach of fiduciary duty and lack of informed consent, it rejected his claim for conversion and a right to share in the profits resulting from the Mo cell line because his spleen was not his property. ${ }^{4}$ Despite its apparent rejection of the property label, however, Moore advanced no alternative paradigm. The case does not stand for the proposition that body parts can never become property, for surely theft of Moore's spleen cells from the scientists' laboratory would have been actionable, ${ }^{5}$ as one dissenting justice pointed out. ${ }^{6}$ Instead, it simply held that Moore's spleen was not his property.

But few may be familiar with two more recent cases, Greenberg v. Miami Children's Hospital ${ }^{7}$ and Washington University $v$. Catalona. ${ }^{8}$ Greenberg goes one step further than Moore by holding not only that the blood, tissue, and other body parts that the Greenbergs supplied were not their property, but also that the gene responsible for their disease was the property of the scientists who isolated it and the hospital that patented it rather than the persons in whose bodies it remained. Several significant differences exist between Moore and Greenberg. First, the researchers who owned the patent on the Canavan gene did not create the gene but merely "discovered" it, unlike those who made the Mo cell line. Second, unlike Moore, the Greenbergs actively participated in the quest to locate the gene for Canavan's disease by contributing their biological samples. Finally, unlike Moore, the Greenbergs sought to make the results of this research freely available to all rather than to share in the profits produced by the patent. Nevertheless, the court mechanically applied Moore to reject their claims.

And Washington University $v$. Catalona goes far beyond both Moore and Greenberg by making explicit what was only implicit in those cases. In Catalona, the court concluded that not just intellectual property in the body but also tangible physical parts of the body (e.g., blood, DNA, and tissue samples) were owned by the university that stored them in its Biorepository rather than the patients from whose bodies these biological materials had been derived. Both cases are notable not just for their conclusions but also for their language and reasoning; thus, they are described in greater detail below.

\section{GREENBERG V. MIAMI CHILDREN'S HOSPITAL}

Canavan disease is a rare genetic disease most prevalent among Ashkenazi Jews that is both incurable and fatal. ${ }^{9}$ In 1987, after Daniel and Debbie Greenberg had given birth to two children diagnosed with Canavan disease, they sought out a researcher, Dr. Reuben Matalon, to study the disease. ${ }^{10}$ Over the years, the Greenbergs supplied Matalon with blood, urine, and tissue samples, and when their two children died, they even donated pieces of their brain to the research. ${ }^{11}$ The Greenbergs located over 100 other Canavan families around the world and convinced them to provide 
blood, urine, and tissue samples too; together they created a Canavan registry - a confidential database compiling epidemiological, medical, and other personal information about the Canavan families. ${ }^{12}$ The Greenbergs also provided financial support for the research, including a grant of about $\$ 100,000$ in seed money. ${ }^{13}$ As Daniel Greenberg commented, "All the time we viewed it as a partnership. Our model was the testing program for Tay-Sachs disease. That's what we hoped would happen again."14.

In their complaint, the plaintiffs alleged that they provided Matalon with all this bodily property, personal information, and financial support "with the understanding and expectation that the samples and information would be used for the specific purpose of mutations."21 The plaintiffs alleged that they were unaware of $\mathrm{MCH}$ 's intent to commercialize the results of this research, and that if they had known this fact, they would not have contributed to the project. ${ }^{22}$ In their complaint, the plaintiffs alleged that the defendants did not present them with a written consent form until 1994. ${ }^{23}$ They argued that this form was inadequate because it failed to disclose the researchers' commercial interests, describing the defendants' purpose only as "identifying mutations in the Canavan gene which could lead to carrier detection within their families and benefit the population at large." ${ }^{24}$ One of the parents Judith Tsipis stated, "We gave our samples to be used for the public good. They were not given to Miami Children's. Had they told us they wanted

\section{The court further ruled that, even if a medical researcher does have some duty to gain informed consent, this duty does not require disclosure of the researcher's economic interests because of the practical implications of retroactively imposing such a duty.}

researching Canavan disease and identifying mutations which could lead to carrier detection within their families and benefit the population at large." 15 They also alleged that it was their "understanding that any carrier and prenatal testing developed in connection with the research for which they were providing essential support would be provided on an affordable and accessible basis, and that Matalon's research would remain in the public domain to promote the discovery of more effective prevention techniques and treatments and, eventually, to effectuate a cure for Canavan disease." 16

In 1993, Dr. Matalon succeeded in isolating the gene responsible for Canavan disease, and in 1994, a patent application was filed. ${ }^{17}$ In 1997, the U.S. Patent and Trademark Office issued Patent $\# 5,679,635$ to the Miami Children's Hospital ( $\mathrm{MCH}$ ), listing Matalon as the inventor. ${ }^{18}$ As a result of this patent, $\mathrm{MCH}$ gained the ability to restrict any activity related to the Canavan disease gene, including carrier and prenatal testing, gene therapy, and other treatments for Canavan disease involving the gene and its mutations. ${ }^{19}$

The plaintiffs alleged that they did not learn of the existence of the patent until November 1998, when $\mathrm{MCH}$ revealed its intention to limit Canavan disease testing through a campaign of restrictive licensing of the patent. ${ }^{20} \mathrm{MCH}$ sent out letters to laboratories that offered Canavan testing, threatening "to enforce vigorously their intellectual property rights relating to carrier and patient DNA tests for Canavan disease to patent it, we probably would have found another researcher who has the same goals as we did. Finding the gene is not an impossible task." 25

According to one scholar, $\mathrm{MCH}$ had a two-stage licensing plan to market the Canavan gene patent. ${ }^{26}$ In the first stage, a limited number of academic labs would be granted nonexclusive licenses to perform a limited number of tests at a fixed price of $\$ 12.50$ per test. ${ }^{27}$ In the second stage, $\mathrm{MCH}$ would license a large commercial lab as a market leader with an exclusive license to the remainder of the testing volume, allowing the lab to engage in monopolistic pricing. ${ }^{28}$

The plaintiffs filed suit against defendants Dr. Matalon and Miami Children's Hospital, asserting six causes of action: (1) lack of informed consent, (2) breach of fiduciary duty, (3) fraudulent concealment, (4) conversion, (5) misappropriation of trade secrets, and (6) unjust enrichment. ${ }^{29}$ Plaintiffs sought a permanent injunction to prevent defendants from enforcing their patent rights, as well as damages, including all royalties defendants received on the patent and the return of financial contributions made by plaintiffs to support the research. ${ }^{30}$ The district court granted the defendants' motion to dismiss all of the plaintiffs' claims except the claim for unjust enrichment. ${ }^{31}$

The Greenberg court rejected the plaintiffs' claim for lack of informed consent, distinguishing Moore on the grounds that Dr. Matalon was acting as a researcher, rather than a physician; thus, he had no legal duty to the plaintiffs who were not his patients. The court fur- 
ther ruled that, even if a medical researcher does have some duty to gain informed consent, this duty does not require disclosure of the researcher's economic interests because of the practical implications of retroactively imposing such a duty. ${ }^{32}$ Specifically, the court thought such a duty "would be unworkable and would chill medical research," and that it "would give rise to a type of dead-hand control that research subjects could hold because they would be able to dictate how medical research progresses." ${ }^{33}$ The court dismissed the plaintiffs' claim for breach of fiduciary duty based upon similar reasoning, finding that "there is no automatic fiduciary relationship that attaches when a researcher accepts medical donations." ${ }^{34}$

Yet the Greenberg court relied upon Moore to reject the plaintiffs' claim for conversion, holding that the plaintiffs' body tissue and genetic information "were donations to research without any contemporaneous expectations of return and thus conversion does not lie as a cause of action." ${ }^{35}$ According to the court, property rights in the body are limited and "the property right in blood and tissue samples evaporates once the sample is voluntarily given to a third party." ${ }^{6}$ The court also repudiated the plaintiffs' argument that the genetic information contained within their bodies constituted a separate property interest distinct from the tissue itself. ${ }^{37}$ The court conceded that "where information is gathered and arranged at some cost and sold as a commodity on the market, it is properly protected as property," but reasoned that this argument provides more support for property rights in the defendants'research rather than the donations of the plaintiffs' $D N A .^{38}$

The one claim that the Greenberg court allowed to go forward - unjust enrichment - never went to trial because the parties ultimately reached a settlement agreement. The plaintiffs consented to abandon their legal challenge to MCH's ownership and licensing of the Canavan gene patent, for which $\mathrm{MCH}$ would continue to collect royalties for clinical testing, in exchange for MCH's promise to permit free use of the gene in research to cure Canavan disease, including gene therapy research and genetic testing in pure research. ${ }^{39}$

\section{WASHINGTON UNIVERSITY V. CATALONA}

In Washington University $v$. Catalona ${ }^{40}$ the plaintiff Washington University (WU) filed a declaratory judgment action seeking to establish ownership of biological specimens of blood, DNA, and prostate tissue that were contributed by patients and housed in the Genito-Urinary (GU) Repository for the purpose of prostate cancer research. ${ }^{41}$ The defendants were the patients themselves, who were labeled "research participants" by the district court, ${ }^{42}$ and they believed that they retained ownership of the biological specimens they had contributed to the GU Repository.43 Moreover, the defendants had all signed informed consent forms which typically stated that they were making "a free and generous gift of your [blood, tissue and/or DNA] to research that may benefit others" but also provided that "your participation is voluntary and you may choose not to participate in this research study or withdraw your consent at any time." 44 Based upon these forms, defendants claimed the right to withdraw their biological materials from WU and transfer them to Dr. Catalona at his new post at Northwestern University. ${ }^{45}$

The district court refused to recognize any property rights in the patients who supplied the biological materials stored in the GU Repository. ${ }^{46}$ Instead, the court ruled that "plaintiff Washington University owns all biological materials, including but not limited to blood, tissue, and DNA samples, in the GU Repository" ${ }^{47}$ The court reached this result based upon the circular reasoning that WU was currently in possession of the biological materials and had continually asserted its ownership interests in the materials. ${ }^{48}$ To buttress this conclusion, the court quoted a number of WU documents, including an Intellectual Property Policy, which asserted that "all intellectual property (including tangible research property) shall be owned by the university if significant university resources were used or if it is created pursuant to a research project funded through corporate, federal, or other external sponsors administered by the University," as well as Material Transfer Agreements (MTAs), which also affirmed WU's ownership of biological materials. ${ }^{49}$ In addition, the court concluded that the defendants were "donors" who had made inter vivos gifts of their biological materials to WU, even though the defendants themselves argued that they had always intended to retain ownership rights. ${ }^{50}$ The court reached this conclusion by focusing upon the language in the informed consent forms, stating that patients were making a "gift" of their biological materials for research, as well as the surrounding circumstances..$^{51}$ In so doing, the court failed to give effect to the limiting language in the same forms that guaranteed those who donated biological materials the right to withdraw from such research at any time. ${ }^{52}$ The court interpreted this language exceedingly narrowly, concluding that it gave patients only the right not to donate additional biological materials, and not the right to withdraw samples already stored in the biorepository. ${ }^{53}$

\section{B. The Body Under Contract}

When courts have refused to protect body parts as property, some individuals have turned to the law of 
contract in an attempt to assert control over the use and transfer of their own bodies. For example, in 1994, Sharon and Patrick Terry discovered that they had passed on a rare genetic disease, pseudoxanthoma elasticum (PXE), to their children. ${ }^{54} \mathrm{PXE}$ is classified as an "orphan disease" because it affects only one in 25,000 births, so pharmaceutical companies were reluctant to invest in research because of the small revenues anticipated from any results..$^{55}$

The Terrys realized that individuals who have the PXE gene are in the best position to control the direction of research because they possess the most valuable resource for researchers: their own diseased blood and tissue..$^{56}$ Thus, the Terrys located over 2,000 individuals with the gene, set up a blood and tissue bank, and incorporated their network into a non-profit organization, PXE International. ${ }^{57}$ They made the novel decision to retain ownership of their blood and tissue through the vehicle of contract law. ${ }^{58}$ As described in an article in American Lawyer, "The Terrys decided to act like many property owners - building a fence around their property and granting access to it only in exchange for something of value. The property in question is the blood of a thousand PXE patients and their families." 59 Before researchers can access the blood and tissue, they must sign a contract saying that they will share with PXE International the ownership and profits on any research from the samples. ${ }^{60}$

In February 2000, PXE International's efforts paid off when Charles Boyd, a pathobiologist at the University of Hawaii, isolated the gene responsible for PXE. ${ }^{61}$ Boyd listed Sharon Terry as one of the co-inventors when he submitted the gene's patent application because he felt that she had served as the catalyst for the success of the gene search. ${ }^{62}$ However, Boyd's contract with the University of Hawaii stated that he would relinquish all future intellectual property rights in the results of his research to the university. ${ }^{63}$ Initially, the university was unwilling to give up control over licensing because it wanted to recoup the costs of filing the patent and to collect some royalties, but PXE International offered to cover all those costs and to share royalties equally if the university would transfer control over licensing, and the university accepted this offer. ${ }^{64}$

\section{The Private Body}

1. THE BODY AS A PUBLIC RESOURCE

In at least one instance, body parts and the information contained in them were treated as a public resource that could be taken by the state and bestowed upon a private party. In 1998, the Icelandic Parliament (the Althingi) enacted the Health Sector Database Act (HSDA), which authorized the Minister of Health to grant an exclusive 12-year license to a private company to create and maintain an electronic database containing all of the health records of the Icelandic people. ${ }^{65}$ These medical records are derived from the country's national health care system and contain the results of lab tests, diagnoses, treatments, and the outcome of such treatments for almost every Icelander living or dead since $1915,{ }^{66}$ as well as tissue samples preserved in wax blocks of every Icelander who has been autopsied since the $1930{ }^{67}$ The government granted this exclusive license to deCODE Genetics, a for-profit Delaware corporation, which planned to use it to construct a centralized database linking the medical records with detailed genealogical records that date back to the 9th century. The database would also show genetic information that the company obtained from over 110,000 Icelanders who voluntarily donated blood samples. 68

The HSDA denies that these medical records are "property," asserting that they cannot be subject to ownership because they are the result of patient treatment. ${ }^{69}$ The Notes to the law provide, "Due to the nature of the data and their origin they cannot be subject to ownership in the usual sense. Institutions, companies or individuals cannot therefore own the data. They exist primarily due to the treatment of patients."70 At the same time, however, the Notes appear to contradict this conclusion by labeling the medical records "a national resource." Moreover, the HSDA itself appears to commodify the medical records by treating them as a form of property that has essentially been seized by the state and sold to a private company. ${ }^{71}$

Indeed, the HSDA grants deCODE the sole right to commercially exploit the medical records database in exchange for funding its construction. ${ }^{72}$ Article 5 requires that licensees pay for the costs of acquiring these records from health institutions and selfemployed health workers, ${ }^{73}$ and Article 10 provides that "the licensee is authorized during the period of the license to use the data on the database for purposes of financial profit." 74 All that deCODE promised in return for the right to profit from this information was that it would provide Icelanders with free access to any resulting drugs for the patent period. ${ }^{75}$ Article 5 of the HSDA also requires the database to be located exclusively in Iceland ${ }^{76}$ and bans the export of Icelandic blood and DNA for research purposes. 77 This provision was intended to prevent "helicopter science," the common research practice of drawing blood samples from native populations and then flying away never to be heard from again, in order to ensure that the people of Iceland would share in the financial profits generated from this research. ${ }^{78}$ The hope was that deCODE's presence would provide jobs for Iceland's 


\section{Intangible intellectual property in the body, such as a gene patent or} a cell line, receives much more protection than physical body parts. The "inventor" or "discoverer" of intellectual property in the body is granted broad protection that extends across space and time, unlike the individuals who are seen as supplying "the raw materials" - e.g., the blood, tissue, and other body parts necessary to conduct such research.

scientists and thereby reverse the brain drain out of the country, as well as foster the growth of a domestic biotech industry to diversify Iceland's cod-fishing economy. ${ }^{79}$

The HSDA does not require affirmative informed consent by patients before deCODE can access, compile, and profit from their medical records. ${ }^{80}$ Instead, the Act presumes consent, forcing patients to opt out if they do not wish to have their medical records included in the database. ${ }^{81}$ By 2002, more than 20,000 people had actively opted out of the medical records database, ${ }^{82}$ although critics contend that even more people would have opted out if the government had publicized the dangers inherent in giving a private company rights over such personal information. ${ }^{83}$ What exactly does "presumed consent" mean? According to deCODE officials, "[p]resumed consent is a nebulous concept, but...we regard it as the consent of society to the use of health care information according to the norms of society." 84 Yet the presumed consent standard applies only to medical records, not to the provision of genetic information. ${ }^{85}$ Thus, those who supply genetic information must give their informed consent in writing before contributing blood samples. ${ }^{86}$ About 110,000 Icelanders have volunteered to provide blood samples for deCODE's genetic database, a number that represents roughly half the total adult population and includes more than 90 percent of people over age $65 .{ }^{87}$

\section{THE TURN TO PRIVACY}

The rejection of property in the human body often leads to invocation of a right to privacy. Thus, the constitutionality of the HSDA was challenged in Ragnhildur Gudmundsdottir $v$. Iceland, which addressed privacy rather than property rights in genetic information. ${ }^{88}$ The plaintiff filed a lawsuit objecting to the inclusion of her dead father's information in the medical records database on grounds that it violated her own right to privacy under Article 71 of the Icelandic Constitution, which provides, "Everyone shall enjoy the privacy of his or her own life, home, and family."89 In an opinion published in English on April 1, 2004, the Icelandic Supreme Court found the HSDA uncon- stitutional because it failed to protect personal privacy adequately..$^{\circ 0} \mathrm{Her}$ father had not consented to the use of his own health records, and Ms. Gudmundsdottir had legal standing to sue because her father's medical history could reveal information about her own health, implicating her personal right to privacy.91 Accordingly, the Court granted Ms. Gudmundsdottir the right to prohibit the transfer of her father's information into the medical records database..$^{92}$

\section{Property, Contract, or Privacy?}

Although each of these situations appears to embody a different paradigm for legal regulation of the human body, all of them actually exemplify the body as property. Both Moore and Greenberg declare that the body is not property, but this conclusion does not follow from the logic of the opinions. The courts equate their holding that body parts are not private property owned by the plaintiffs with the theory that the body is not property at all. Despite this language, they actually treat body parts as a kind of property, free for "capture" by the first person who recognizes their commercial potential and puts them to productive use. In other words, Moore and Greenberg apply the property law of capture to body parts in much the same way that other courts have applied the law of capture to migratory resources such as oil, water, and wild animals. ${ }^{93}$ Hence, they award ownership not to Moore or the Greenbergs, but rather to the researchers who created the Mo cell line from Moore's spleen cells and those who isolated the gene for Canavan's disease using patients' blood and body parts.

Moreover, Justice Broussard's dissent suggests that the court probably would have been willing to protect the property rights of the scientist who used Moore's spleen to create the Mo cell line by permitting him a cause of action for conversion if a rival researcher had stolen the spleen from his lab. ${ }^{94}$ Justice Broussard proved prescient when his hypothetical came to life in Washington University v. Catalona, which granted Washington University ownership of biological samples donated by patients over the objections of a researcher who had relocated to another university and the patients themselves. Catalona makes it crystal 
clear that physical body parts - not just cell lines and genetic sequences - do receive property protection when they are in the possession of a research institution rather than an ordinary person. By holding that body parts are free for appropriation by the scientists who transform them into useful products, all of these cases actually appear to regard the human body as res nullius, a form of property that belongs to no one and is part of the public domain. The analogy to wild animals, water, and other natural resources is obvious. Moore's description of the wrong done to him is quite revealing: "My doctors are claiming that my humanity, my genetic essence, is their invention and their property. They view me as a mine from which to extract biological material. I was harvested."95

The government of Iceland also asserts that body parts and medical records are not property subject to ownership. ${ }^{96}$ Once again, this confuses the concept that these items are not property with the idea that they are not private property, but rather belong to the community. By putting them to public use as a "natural resource," the government actually characterizes body parts and information as res communis, a form of property that belongs to everyone to be used for the common benefit. ${ }^{97}$

Only the PXE contract is truly agnostic on the question whether the body is property. Privacy rights could serve as the basis for the contractual exchange, as well as property. Yet the PXE contract itself created a kind of ownership of the human body. Specifically, it enabled individuals to exert control over the use and transfer of their body parts - two of the essential attributes of property. Furthermore, by focusing upon the sharing of profits from the commercial benefits of the research, rather than issues of consent and confidentiality, the PXE contract also seems to speak in the language of property rather than privacy.

\section{A. Problems with the Property Paradigm}

All of these cases effectively treat the body as a type of property. Indeed, propertization of the human body proceeds inexorably whether or not the law acknowledges this reality. ${ }^{98}$ Yet profound problems plague the property paradigm. First, property law seems to systematically favor certain categories of resources, in the hands of some kinds of people, much more than others. Thus, intangible intellectual property in the body, such as a gene patent or a cell line, receives much more protection than physical body parts. The "inventor" or "discoverer" of intellectual property in the body is granted broad protection that extends across space and time, unlike the individuals who are seen as supplying "the raw materials" - e.g., the blood, tissue, and other body parts necessary to conduct such research. Bodily property, on the other hand, is conceived as a tangible thing that is protected only insofar as it remains in the possession of its "owner," or that may be deemed unownable and thus not protected at all.

The California Supreme Court, for example, rejected Moore's conversion claim on grounds that his spleen was not his property. And the Greenberg court suggested that ownership of tangible bodily property (blood and tissue) is so fleeting that it "evaporates" as soon as the body part leaves the individual's possession. ${ }^{99}$ Accordingly, the court also denied the Greenbergs' claim for conversion. ${ }^{100}$ Yet in United States $v$. Arora, ${ }^{101}$ the court was willing to recognize a cause of action for conversion when one researcher intentionally destroyed a rival scientist's cell line, which was part of a valuable research project. ${ }^{102}$

Why are courts willing to allow a claim for conversion in one context but not the other? The contradictory treatment of property in the human body may flow from the distinction between physical body parts and intellectual property in the body. Specifically, body parts are characterized as "raw materials" to be harvested, whereas human genes and cell lines are conceptualized as man-made products. Yet even tangible body parts - not just cell lines and genetic sequences - receive property protection when they are in the possession of a researcher rather than an ordinary person. Thus, Washington University $v$. Catalona awarded ownership over pure body parts - blood and tissue samples that had not been transformed into a distinct product - to the research institution that stored them rather than the patients who supplied them.

All of these cases afford property rights to the researchers who isolate the gene or create a cell line over the persons from whose bodies the purified gene or cell line is derived. Perhaps this is attributable to a labor theory of property that values the intellectual work that researchers perform more than the "raw materials" patients provide. But if we consider Greenberg from a different perspective, the only really unique and indispensable contribution to the research on the Canavan gene was provided by the families who supplied their blood, tissue, and the bodies of their dead children, as well as their private medical information. ${ }^{103}$ The intellectual capital contributed by Dr. Matalon and the financial capital supplied by Miami Children's Hospital were entirely fungible, unlike the very "personal" property ${ }^{104}$ provided by the families. ${ }^{105}$ Yet those who contributed fungible intellectual and financial capital received much more extensive protection under the law of property than those who contributed the intimate body parts and medical information that were absolutely indispensable to such research. 
Furthermore, property law favors those who plan to commodify and commercialize human genes over those who resist commodification in order to make genetic resources freely available to all. Thus, the Greenberg court also rejected the plaintiffs' argument that the genetic information contained within their bodies was their property, but suggested that it became the property of the researchers once it had been commodified. ${ }^{106}$ The court conceded that "where information is gathered and arranged at some cost and sold as a commodity on the market, it is properly protected as property," but reasoned that this argument provided more support for property rights in the defendants' research rather than the donations of the plaintiffs' DNA. ${ }^{107}$ The court's logic reveals that property implicitly privileges some notions of value over others. Utilitarian and commercial values appear to predominate over other values, which are often ignored or not capable of being fully articulated in the language of property law. In addition, property law appears to be skewed towards certain kinds of regimes over others: private property appears to hold sway over communal property and the public domain. Thus, the researchers' commercial plans for the Canavan gene prevailed over the Greenbergs' altruistic desire to share this information with others in order to prevent disease. All of this suggests that property law has a hidden bias towards capitalist markets and private property, over sharing and the public domain.

Ironically, not only did the court reject the Greenbergs' argument that the Canavan gene patent should remain part of the public domain because that was their intent, but instead the court ruled that it was their bodies and their genes - and not the gene isolated by Dr. Matalon - that were in the public domain, free for appropriation by the first researcher who came along and reduced them to private possession. ${ }^{108}$ All of these examples demonstrate the lopsided treatment of property in the human body, which furthers the transformation of the "raw materials" harvested from human bodies into the man-made products of science.

\section{B. Flawes in the Contract Framework}

The PXE example appears to avoid many of the problems present in Moore and Greenberg by resorting to the rubric of contract law. But before romanticizing the realm of private bargaining, we should recognize that flaws exist in the contract framework as well. Contract law's ability to safeguard individuals depends upon their position in the genetic market, as well as their level of knowledge and power. It seems to work well in the context of "orphan diseases," where a small pool of people with a gene may unite to wield disproportion- ate bargaining power. But it may not work as well in other contexts, such as the following: (1) when individuals, rather than groups, or single transactions are involved because the transaction costs of contracting would generally outweigh the value of the contribution, thereby discouraging socially valuable research; (2) when it is difficult for individuals to organize because they suffer from a widespread disease that afflicts many; or (3) when individuals lack sufficient knowledge or power to be able to contract effectively.

Moreover, contract law binds only those who are parties to the agreement, not the whole world. ${ }^{109}$ The PXE case, for example, never went to court, so it is unclear whether the contract between the Terrys and the researcher who discovered the PXE gene would have been enforced against the University of Hawaii, especially in the face of the researcher's rival contract with the university. ${ }^{110}$ It is not even clear whether body parts can form the basis of such a contract if they are not property for purposes of conversion law. If body parts are not property, can their exchange provide adequate consideration to support such a contract? And would a court be willing to enforce such a contract, or would it be held void as contrary to public policy?

In addition, the PXE families succeeded only insofar as their goal coincided with that of the University of Hawaii - to keep the patented gene private property, with the proceeds shared equally between the patients and the university." ${ }^{111}$ But it is not so clear that the result would have been the same had PXE International's goal been to leave the gene in the public domain, freely available to all. Accordingly, both property and contract appear to push towards protection of intellectual property in the body as private property, rather than public or communal property. Ironically, private property in human genes - even when ownership lies in those afflicted by the disease, rather than the researchers or the hospitals - may result in injustice. In the case of the PXE gene, the patent is owned by PXE International, which can control use of the gene and the terms of licensing in the interests of its "owners." However, PXE International has no incentive to take into account the welfare of other persons who also possess an interest in the gene, such as the large number of persons with heart disease, which may be linked to the PXE gene. ${ }^{112}$

It is possible to view the Terrys and other families with the PXE gene as subjects who took charge of their own destiny, rather than mere objects of property: they flouted the norms of property doctrine to self-consciously construct a distinct form of property in the human body by means of contract. Yet at the same time, they too were trapped within the dominant paradigm, constrained to reproduce and reflect 
its characteristics by contracting to gain ownership of their own gene. Their contract was successful insofar as it accomplished the private ownership of human genes, unlike the Greenbergs, who sought to keep their genes in the public domain. In so doing, the Terrys unconsciously reproduced and perpetuated a property paradigm they appeared to evade, and they inadvertently gained the power to perpetrate upon others exactly the same types of injustice they themselves sought to avoid. This is because their private property rights may have negative consequences for other groups who share an interest in the PXE gene, so that the inequality between the Greenbergs and Miami Children's Hospital is mirrored by the imbalance of power between those with PXE and others for whom the gene also holds importance.

Iceland's unique approach appears to promise a way out of this dilemma. Rather than treating body parts as private property or as part of the public domain, this approach treats body parts as public property to be used for the good of society. However, it is not clear that the public will actually benefit from the exclusive license granted to deCODE, especially in relation to the huge private profits expected to accrue to the corporation. ${ }^{113}$ The fact that the public good is accomplished by giving the "natural resource" to a private corporation provokes concerns regarding the possibility of government capture or corruption. Moreover, this transaction has been labeled a form of "bio-piracy," the exploitation of Iceland's people for the profit of a private corporation that has been granted a dangerous monopoly over a valuable resource that should benefit everyone. ${ }^{114}$ Thus, Iceland's experience seems to illustrate the problems of the contract model writ large, representing both the dangers of privatization and the risk that poor or small countries will enter into unequal bargains with wealthy, powerful corporations.

\section{The Inadequacy of a Privacy Interest}

If property and contract are two sides of the same coin, with each part of a free market model pushing for commodification and commercialization of the human body, then why not protect the body under the rubric of privacy? Both property and privacy encompass the right to possess one's own body, to exercise a certain degree of control over it, and to exclude others. ${ }^{115}$ Yet property protects the autonomy of the "owner" over that which is owned, whereas privacy safeguards an inviolable corporeal identity. ${ }^{16}$ Property envisions a person who "owns" and is thus distinct from his or her body, whereas privacy views the person as embodied and the body as personified.117 Under property theory, a person only loosely inhabits his or her body; the self is independent of its physical embodiment. Privacy, by contrast, treats the body as integrally connected to the person, such that invasions of the physical being endanger its essential personhood. ${ }^{118}$

Accordingly, property theory severs the body from the person who owns it, whereas privacy theory maintains the two as indivisible and inextricably intertwined. As property, the body can be detached from its "owner" and fragmented into discrete components, allowing it to be manipulated, transformed, alienated on the market, or even seized by the state upon payment of just compensation. Privacy, on the other hand, bundles all interests in the body together within a single person. As a result, bodily privacy is generally inalienable and unassailable: it can neither be contracted away to private parties nor confiscated by the government.

In Property, Privacy, and the Human Body ${ }^{119}$ I set forth three principles to determine whether the body should be protected as the subject of a privacy interest or the object of property ownership: (1) whether it is living or dead; (2) whether it is integrated with the whole person or a separate part; and (3) whether it is involved in a personal relationship or an object relationship. ${ }^{120}$ Applying these three principles, genetic material should be protected under the rubric of privacy when individuals allege that their genes are an inalienable part of their personal, familial, or cultural identity. ${ }^{121}$ For example, privacy would encompass individuals' claims that the extraction of their genetic materials infringes upon their right to exclude others from their bodies, or that publication of genetic information violates their right to keep their genetic identities secret in order to protect their individual and familial privacy and prevent discrimination.

These were exactly the kinds of harms alleged in Ragnhildur Gudmundsdottir v. Iceland. The plaintiff refused to allow her own medical records to be included in the database. ${ }^{122}$ But she also claimed that her personal right to privacy would be violated by the transfer of her dead father's information into the medical records database because he had not personally consented to such use, and because his medical history could reveal intimate information about her own health. ${ }^{123}$ Unlike property, the government cannot "take" individuals' privacy rights without their consent, even upon payment of "just compensation." 124

Yet the privacy paradigm does not really apply to cases such as Greenberg and Catalona because the research subjects in those cases objected neither to the severing of their blood, tissue, and body parts from their body, nor to the publication of their genetic information. To the contrary, they voluntarily "donated" their own body parts to research. What they protested was not the fragmentation of their body and the extrac- 
tion of their genetic information, but rather the acts of privatization and commercialization. ${ }^{125}$ Moreover, the privacy paradigm implicitly requires situations of intimacy and relationships that may not exist between researchers and those who participate in biomedical research. Thus, the Greenberg court also rejected the plaintiffs' privacy claims for breach of fiduciary duty and lack of informed consent, based upon the absence of relationships of trust between researchers and their subjects. ${ }^{126}$ Finally, the goal of the Greenbergs was to make the research freely available to the public rather than to keep such genetic information private, which seems to contradict the very premise of privacy theory.

More fundamentally, property is such a powerful and pervasive paradigm that propertization of the human body often takes place whether or not it is acknowledged explicitly. Privacy cannot counter the right of property: it offers inadequate protection to those who provide the "raw materials" of biomedical research if everyone else is permitted to commodify and commercialize the human body. Washington University $v$. Catalona reveals that the privacy right to informed consent includes only the right to give or withhold body parts for medical research, but it does not encompass the right to control or direct the research in any way. Moreover, it does not even include the right to be informed of the potential profits to be reaped from such research or of researchers' plans for privatization. In the face of substantial property rights on the part of researchers and research institutions, such meager privacy interests leave those who supply body parts too vulnerable to exploitation.

\section{Conclusion}

On the one hand, property law seems to be systematically biased in favor of some categories of property in the human body and some kinds of ownership over others. Specifically, property privileges those who plan to commodify and commercialize human genes over those who wish to make genetic resources freely available to all. On the other hand, contract and privacy rights cannot compete with the powerful property paradigm, which alone affords a complete bundle of rights that are enforceable against the whole world. In the face of strong property rights on the part of researchers and research institutions, the theoretical freedom to contract and the meager interest in privacy leave those who supply body parts vulnerable to exploitation.

So what is to be done to protect those who wish to donate their body parts to biomedical research while retaining a measure of control over the products of such research? Perhaps we should transform the mod- ern law of property in the human body by resurrecting an older strand of property theory that has been long dormant - the concept of property as stewardship. Indeed, John Locke's famous statement that "every Man has a Property in his own Person" embodies this vision of property in the body because he viewed individuals as stewards over their bodies, possessing themselves in trust rather than as outright owners. ${ }^{127}$ Precisely such an approach is advocated by David Winickoff, who innovatively applies charitable trust law in an attempt to create a partnership between biomedical researchers and research subjects in the context of genomic biobanks. ${ }^{128}$ Winickoff's charitable trust model may provide a way out of the puzzling dilemmas posed by existing property, contract, and privacy rights in human genes and spleens.

\section{References}

1. See R. Rao, "Property, Privacy, and the Human Body," Boston University Law Review 80, no. 2 (2000): 359-460, at 359 (contrasting property and privacy rights in the human body).

2. For example, the National Academy of Sciences Guidelines and California law prohibits compensation of those who supply eggs for human embryonic stem cell research, yet they permit patents to be granted upon the products of such research. See R. Rao, "Coercion, Commercialization, and Commodification: The Ethics of Compensation for Egg Donors in Stem Cell Research," Berkeley Technology Law Journal 21, no. 3 (2006): 1055-1066, at 1055 .

3. Moore $v$. Regents of the University of California, 793 P.2d 479 (Cal. 1990).

4. Id.

5. Indeed, the same scientists who contested Moore's property claim apparently viewed themselves as the owners of his spleen, heedless of the irony inherent in their position. In a parallel case that was subsequently settled out of court, these scientists brought suit against several other researchers who used the spleen cells without obtaining their consent. $I d$., at 497.

6. Justice Broussard's argument was as follows: "Although the majority opinion....appears to suggest that a removed body part, by its nature, may never constitute 'property' for purposes of a conversion action, there is no reason to think that the majority opinion actually intends to embrace such a broad or dubious proposition. If, for example, another medical center or drug company had stolen all of the cells in question from the UCLA Medical Center laboratory and had used them for its own benefit, there would be no question but that a cause of action for conversion would properly lie against the thief, and the majority opinion does not suggest otherwise." Id., at 501 .

7. Greenberg v. Miami Children's Hospital, 264 F. Supp. 2d 1064 (S.D. Fla. 2003) [hereinafter cited as Greenberg].

8. Washington University v. Catalona, 437 F. Supp. 2d 985 (E.D. Missouri 2006).

9. See Greenberg, supra note 7, at 1066; see also G. Kolata, "A Special Report: Who Owns Your Genes?” New York Times, May 15, 2000, at A1.

10. Id.; see also P. Gorner, "Parents Suing over Patenting of Genetic Test," Chicago Tribune, November 19, 2000, at 1.

11. See Greenberg, supra note 7 , at 1066; see also id.

12. Id.

13. See Kolata, supra note 9; Greenberg, supra note 7; E. Marshall, "Families Sue Hospital, Scientist for Control of Canavan Gene," Science 290, no. 5494 (November 10, 2000): 1062. "Matalon acknowledges that the Canavan parents helped him to get started by contributing tissue and 'seed money' amounting to no more than $\$ 100,000$." 
14. See Gorner, supra note 10.

15. See Complaint at 7, Greenberg $v$. Miami Children's Hospital, 264 F. Supp. 2d 1064 (S.D. Fla.2003) (No. 00C-6779).

16. Id., at 8 .

17. See Greenberg, supra note 7 , at 1067.

18. Id.

19. Id.

20. See Amended Complaint at 11, Greenberg v. Miami Children' Hospital, 264 F. Supp. 2d 1064 (S.D. Fla.2003) (No. O222244); Greenberg, supra note 7 , at 1067 .

21. See Amended Complaint at 11-12, Greenberg v. Miami Children's Hospital, 264 F. Supp. 2d 1064 (S.D. Fla.2003) (No. 02-22244).

22. See Greenberg, supra note 7 , at 1068 .

23. Amended Complaint at 11, Greenberg v. Miami Children's Hospital, 264 F. Supp. 2d 1064 (S.D. Fla.2003) (No. 02-22244). "Although Defendants had applied for a patent in 1993, they did not disclose it in the 1994 informed consent form under which they collected blood and undertook genetic analyses of David Green's family, Daniel Greenberg's family, and thousands of individual members of Dor Yeshorim."

24. $I d$, at 7 .

25. See Kolata, supra note 9.

26. See J. F. Merz, "Discoveries: Are There Limits on What May Be Patented?" in David Magnus et al., eds., Who Orons Life? 27. Id. (Amherst, NY: Prometheus Books, 2002): at 99

28. $I d$.

29. See Greenberg, supra note 7 , at 1068 .

30. Id.

3I. Id., at 1077 .

32. Id., at 1070

33. Id., at 1070-71.

34. $I d$., at 1072 .

35. Id., at 1074 .

36. $I d$, at 1075 .

37. Id.

38. Id.

39. Canavan in the News, Press Release, September 29, 2003 , available at <http://www.canavanfoundation.org/news/0903 miami.php> (last visited May 23, 2007).

40. See Washington University, supra note 8.

41. $I d$., at $987-88$.

42. Id., at 989 .

43. Id., at 994 .

44. $I d$., at 990 .

45. Id., at 994 .

46. Id., at 1002 .

47. Id.

48. Id., at 995 .

49. Id., at 989 .

50. Id., at 997-99.

51. Id., at 997 .

52. Id., at 999 .

53. Id., at $999-1000$

54. M. Fleischer, "Patent Thyself," The American Lawyer, June 21, 2001, at 84-100.

55. Id.

56. Id.

57. S. Solovitch, "The Citizen Scientists," Wired, September 1, 2001, at 144-151; see Fleischer, supra note 54.

58. Id. (Fleischer).

60. Id.

61. Id.

62. Id.

63. Id.

64. Id.

65. R. Chadwick, "The Icelandic Database: Do Modern Times Need Modern Sagas?” British Medical Journal 319, no. 7207 (August 14, 1999): 441-444, at 441.

66. Id. See also H. Jonatansson, "Iceland's Health Sector Database: A Significant Head Start in the Search for the Biological Grail or an Irreversible Error?" American Journal of Law and Medicine 26 , no. 1 (2000): 31-68, at 31 .

67. M. Williams Walsh, "A Big Fish in a Small Gene Pool," Los Angeles Times, June 5, 1998, at A1.

68. See Jonatansson, supra note 66; C. Lok, “Translating Iceland's Genes into Medicine," Technology Review 107, no. 7 (September 1, 2004): 58-65; D. E. Duncan, "Tracking Genes in Iceland Sifting Viking Records Yields a Marker for Stroke," San Francisco Chronicle, October 19, 2003, at 1.

69. See Bill on a Health Sector Database, Notes to the Bill, Section 2, available at <http://www.mannvernd.is/english/laws/HSD. 70. Id. bill.html> (last visited June 21, 2007)

71. Id.

72. Id. See also M. Enserink, "Iceland OKs Private Health Databank," Science 283, no. 5398 (January 1, 1999): 13.

73. See Bill on a Health Sector Database, supra note 69 , at Article 5 , Section 8.

74. Id., at Article 10.

75. See M. Enserink, "Physicians Wary of Scheme to Pool Icelanders' Genetic Data; Database of Health Records Would Be Granted to Private Company for Analysis," Science 281, no. 5379 (August 14, 1998): 890-891, at 890.

76. See Bill on a Health Sector Database, supra note 69, at Article 5 , Section 1.

77. See R. McKie, "Iceland's Gene Pool Holds the Key to Curing Diseases," The Observer, November 9, 1997, at 15 .

78. Id.

79. See S. Lyall, "A Country Unveils Its Gene Pool and Debate Flares," New York Times, February 16, 1999, at F1.

80. See Bill on a Health Sector Database, supra note 69 , at Notes to the Bill, Principle Features of the Bill, Section 3.

81. Id., at Article 8; see also Jonatansson, supra note 66 , at $47-48$.

82. A. Abbott, "Icelandic Database Shelved as Court Judges Privacy in Peril," Nature 429, no. 6988 (May 13, 2004): 118.

83. See Lyall, supra note 79; see also G. Annas, "Rules for Research on Human Genetic Variation - Lessons from Iceland," Neze England Journal of Medicine 342 , no. 24 (June 15, 2000): 1830-1833, at 1830; see also S. Sigurdsson, "Decoding Broken Promises," Open Democracy, June 3, 2003, available at <http://www.opendemocracy.net/debates/article-9-79-1024. jsp > (last visited May 10, 2007).

84. J. Gulcher and K. Stefansson, "The Icelandic Healthcare Database and Informed Consent," New England Journal of Medicine 342, no. 24 (June 15, 2000): 1827-1830, at 1827.

85. See Lyall, supra note 79 .

86. Id.

87. See Abbott, supra note 82

88. Ragnhildur Gudmundsdottir v. Iceland, Icelandic Supreme Court, No. 1512003, available at <http://www.epic.org/privacy/ genetic/iceland_decision.pdf> (last visited May 10, 2007).

89. See Abbott, supra note 82; see also G. Annas, "Family Privacy and Death - Antigone, War, and Medical Research," New England Journal of Medicine 352, no. 5 (February 3, 2005): 501505 , at 501.

90. See Abbott, supra note 82; Gudmundsdottir, supra note 88.

91. See Annas, supra, note $89 ; i d$. (Gudmundsdottir).

92. Id.

93. See, e.g., Elliff v. Texon Drilling Co., 210 S.W.2d 558, 561-62 (Tex. 1948) (applying the law of capture to oil and gas); Houston E' T.C. Ry. Co. v. East, 81 S.W. 279, 280-82 (Tex. 1904) (applying the law of capture to groundwater); Pierson $v$. Post, 2 Am. Dec. 264, 264-67 (N.Y. 1805) (holding that wild animals become the property of the first person who captures them or brings them under certain control); see also Rao, supra note I, at $359,373-75,454-456$.

94. See Moore, supra note 3, at 501 .

95. J. Vidal and J. Carvel, "Lambs to the Gene Market," The Guard ian (London), November 12, 1994, at 25.

96. See Bill on a Health Sector Database, supra note 69 , at Notes to the Bill, Section 2. 
97. Iceland's approach resembles U.S. jurisprudence governing dead bodies. For example, many American states authorize the taking of body parts from dead bodies without obtaining consent from the decedent or his or her family. These laws effectively treat dead bodies as a communal resource that may be confiscated by the state for the benefit of the living. See Rao, supra note 1 , at $371,380-381,450-451$.

98. See Rao, supra note 2.

99. See Greenberg, supra note 7, at 1075 (stating that "the property right in blood and tissue samples evaporates once the sample is voluntarily given to a third party").

100. Id., at 1074 .

101. United States v. Arora, 860 F. Supp. 1091 (D. Md. 1994).

102. Id., at 1099.

103. As Jon Merz, a biothethicist at the University of Pennsylvania, said, "There were basically three ingredients that went into the Canavan research. More than 160 families participated in giving DNA samples, urine and blood samples that led to the discovery of the gene. So a key point was the direct participation of people most directly influenced by the disease. Another key point was the number of researchers who had the capability to go ahead and do the research. The Matalon group had no special skills. In fact, they had applied for funding from the National Institutes of Health and they didn't get it because they had no track record in gene research. The third ingredient was money. Miami Children's Hospital obviously threw money at Matalon to do Canavan research. But that's not unique either. A lot of people will fund research. So it turns out the money and research skills were totally replaceable. The only thing that was absolutely required in order to make the discovery was the participation of these families." See Gorner, supra note 10.

104. See M. J. Radin, "Property and Personhood," Stanford Law Review 34, no. 5 (1982): 957-1015, at 957.

105. See Merz, supra note 26; J. F. Merz, "Discoveries: Are There Limits on What May Be Patented?" in D. Magnus, A. Caplan, and G. McGee, eds., Who Owns Life? (Amherst, New York: Prometheus Books, 2002): at 99.

106. See Greenberg, supra note 7, at 1075.

107. Id.

108. Id.

109. See T. W. Merrill and H. E. Smith, "The Property/Contract Interface," Columbia Law Review 101, no. 4 (2001): 773-852, at $773,776-777$ (noting that contract rights are in personam - "they bind only the parties to the contract," whereas property rights are "in rem - they bind 'the rest of the world.")

110. See Fleischer, supra note 54.

111. Id.

112. H. Altann, "UH Discovery May Cut Heart Disease," Honolulu Star-Bulletin, June 2, 2000.

113. See Chadwick, supra note 65.

114. See Walsh, supra note 67.

115. See Rao, supra note 1 , at 418-428.

116. Id., at 428 .

117. Id.

118. Id.

119 See Rao, supra note 1.

120. Id., at 445 .

121. Id., at 459 .

122. Ragnhildur Gudmundsdottir v. Iceland, Icelandic Supreme Court, No. 1512003, available at <http://www.epic.org/privacy /genetic/iceland_decision.pdf $>$ (last visited May 21, 2007). 123. Id.

124. See Rao, supra note 1, at 439-4.42.

125. See Kolata, supra note 9.

126. See Greenberg, supra note 7 , at 1072.

127. See Rao, supra note 1 , at $367-368$.

128. See D. Winickoff and R. Winickoff, "The Charitable Trust as a Model for Genomic Biobanks," Nere England Journal of Medicine 349, no. 12 (2003): 1180-1184. 